Research Article

\title{
Comparative cytogenetics of three species of Dichotomius (Coleoptera, Scarabaeidae)
}

Guilherme Messias da Silva ${ }^{1}$, Edgar Guimarães Bione², Diogo Cavalcanti Cabral-de-Mello ${ }^{1,3}$, Rita de Cássia de Moura ${ }^{3}$, Zilá Luz Paulino Simões ${ }^{2}$ and Maria José de Souza ${ }^{1}$

${ }^{1}$ Centro de Ciências Biológicas, Departamento de Genética, Universidade Federal de Pernambuco, Recife, PE, Brazil.

${ }^{2}$ Departamento de Biologia, Faculdade de Filosofia, Ciências e Letras de Ribeirão Preto, Universidade de São Paulo, Ribeirão Preto, SP, Brazil.

${ }_{3}^{3}$ Instituto de Ciências Biológicas, Departamento de Biologia, Universidade de Pernambuco, Recife, PE, Brazil.

\begin{abstract}
Meiotic and mitotic chromosomes of Dichotomius nisus, $D$. semisquamosus and $D$. sericeus were analyzed after conventional staining, C-banding and silver nitrate staining. In addition, Dichotomius nisus and D. semisquamosus chromosomes were also analyzed after fluorescent in situ hybridization (FISH) with an rDNA probe. The species analyzed had an asymmetrical karyotype with $2 n=18$ and meta-submetacentric chromosomes. The sex determination mechanism was of the $\mathrm{Xy}_{\mathrm{p}}$ type in $D$. nisus and $D$. semisquamosus and of the $\mathrm{Xy}_{\mathrm{r}}$ type in $D$. sericeus. C-banding revealed the presence of pericentromeric blocks of constitutive heterochromatin $(\mathrm{CH})$ in all the chromosomes of the three species. After silver staining, the nucleolar organizer regions (NORs) were located in autosomes of $D$. semisquamosus and $D$. sericeus and in the sexual bivalent of $D$. nisus. FISH with an rDNA probe confirmed NORs location in $D$. semisquamosus and in $D$. nisus. Our results suggest that chromosome inversions and fusions occurred during the evolution of the group.
\end{abstract}

Key words: chromosome rearrangements, heterochromatin, karyotype, NORs, FISH.

Received: August 6, 2008; Accepted: November 27, 2008.

\section{Introduction}

The family Scarabaeidae belongs to the suborder Polyphaga and has approximately 2,000 genera and 25,000 species (Costa, 2000). This family reunites the majority of the New World coleopterans, with 362 genera and 4,706 species in the Neotropical area and about 125 genera and 1,700 species in the Nearctic region (Costa, 2000; Ratcliffe et al., 2002). In Brazil, approximately 204 genera and 1,777 species have been recognized (Costa, 2000). The tribe Coprini presents about 30 genera, including Dichotomius, with more than 750 widely distributed species, from which over 600 occur in the New World and 83 were reported in Brazil (Vaz-de-Mello, 2000; Ratcliffe et al., 2002).

In spite of the large number of Scarabaeidae species described cytogenetic analyses are still scarce in this group and predominantly restricted to standard analysis. Cytogenetic data are available for around 390 scarabaeids

Send correspondence to Maria José de Souza. Centro de Ciências Biológicas, Departamento de Genética, Universidade Federal de Pernambuco, Recife, PE, Brazil. E-mail: mjslopes.ufpe@yahoo.com.br. which corresponds to approximately $1,5 \%$ of the described species (Smith and Virkki, 1978; Yadav et al., 1979; Vidal, 1984; Moura et al., 2003; Bione et al., 2005a, 2005b; Wilson and Angus, 2005; Angus et al., 2007; Dutrillaux et al., 2007; Cabral-de-Mello et al., 2008). Most Scarabaeidae species presented a karyotype with 2n $=20$ with meta-submetacentric chromosomes and a parachute sex chromosome mechanism $\left(\mathrm{Xy}_{\mathrm{p}}\right)$, but the diploid numbers ranged from $2 n=8$ to $2 n=30$ and seven different sex determination mechanisms have been reported (Smith and Virkki, 1978; Yadav et al., 1979; Vidal, 1984; Martins, 1994; Colomba et al., 1996, 2000a; Cabral-de-Mello et al., 2007).

Only some of the Scarabaeidae species had their chromosomes analyzed after banding: 65 species had their chromosomes analyzed after C-banding, base-specific fluorochromes were used in ten species, 14 species were studied after silver staining and 11 were analyzed after fluorescent in situ hybridization (FISH) with a ribosomal DNA (rDNA) probe. In general, species from this family presented constitutive heterochromatin $(\mathrm{CH})$ in the pericentromeric areas of the autosomes and some species showed additional hete- 
rochromatin in interstitial and/or telomeric areas (Moura et al., 2003; Bione et al., 2005a, 2005b; Dutrillaux et al., 2007). Five types of distribution were reported for the nucleolar organizer regions (NORs): 1) NORs located in one autosomal pair, in Lygerus ebenus and Phyllophaga (Phyllophaga) aff capillata; 2) NORs present in more than one autosomal pair, in Gymnopleurus sturmi and Bubas bison; 3) NORs in many autosomes and in the X chromosome, in Diabroctis minas; 4) NORs restricted to the X chromosome, in Phyllophaga (Phytalus) vestita, Lyogenys fuscus, Geniates borelli, Macraspis festiva, Pelidnota pallidipennis and Pentodon bidens punctatum; and 5) NORs in the $X$ and Y chromosomes, in Jumnos ruckeri (Colomba et al., 2000a; Moura et al., 2003; Vitturi et al., 2003; Bione et al., 2005a, 2005b; Mascaine et al., 2007).

The aim of this study was to describe and compare the karyotypes of Dichotomius nisus, D. semisquamosus and D. sericeus (Scarabaeinae, Coprini), using C-banding, silver nitrate staining and FISH with a $28 \mathrm{~S}$ rDNA probe.

\section{Materials and Methods}

Meiotic and mitotic chromosomes of adult males of the genus Dichotomius Hope, 1838 captured from 2003 to 2006 with the use of "pitfall" soil traps were studied. Fifteen specimens of Dichotomius nisus (Olivier, 1789) and 18 of D. semisquamosus (Curtis, 1845) were collected at Aldeia, in the district of Paudalho ( $7^{\circ} 53^{\prime} 48^{\prime \prime} \mathrm{S}, 35^{\circ} 10^{\prime}$ $47^{\prime \prime} \mathrm{W}$ ) and in Brejo Novo, district of Caruaru ( $8^{\circ} 17^{\prime} 0^{\prime \prime} \mathrm{S}$, $\left.35^{\circ} 58^{\prime} 34^{\prime \prime} \mathrm{W}\right)$, state of Pernambuco, Brazil and in the city of Ribeirão Preto ( $21^{\circ} 10^{\prime} 39^{\prime \prime}$ S, $47^{\circ} 48^{\prime} 37^{\prime \prime}$ W), São Paulo, Brazil. The 50 specimens of Dichotomius sericeus (Harold, 1867) were collected exclusively in the localities in the state of Pernambuco.

The individuals were sacrificed, their testes were fixed in Carnoy (3:1 ethanol:acetic acid) and stored in the freezer at $-20{ }^{\circ} \mathrm{C}$. The cytological preparations were obtained using the standard procedure and were stained with $2 \%$ lacto-acetic orcein. C-banding was performed according to Sumner (1972) and silver nitrate staining was performed according to Rufas et al. (1987). For fluorescent in situ hybridization (FISH), the methodology used was that described by Natarajan et al. (1998) and Sakamoto-Hojo et al. (1999). The rDNA fragment used as probe for NOR detection was obtained from an Apis mellifera $28 \mathrm{~S}$ clone (GenBank access number AJ302936). After polymerase chain reaction (PCR) amplification, the resulting fragments were used as templates in another PCR cycle to obtain biotinylated products. Avidin coupled with fluorescein isothiocyanate (FITC) was used for probe detection. The analyses were performed under a Leica microscope and the CytoVision system coupled to an Olympus BX51 microscope was used for obtaining of the photomicrographs. The figures were organized using the Corel Photo-Paint 12 software.

\section{Results}

Dichotomius sericeus, D. nisus and D. semisquamosus presented $2 \mathrm{n}=18$ chromosomes. These species had similar karyotypes with meta-submetacentric chromosomes that showed a gradual decrease in size, except for the especially large pair 1 (Figure 1). As for the sex determining system, Dichotomius sericeus presented a X $\mathrm{y}_{\mathrm{r}}$ mechanism (meioformula $8 \mathrm{II}+\mathrm{Xy}_{\mathrm{r}}$ ) (Figure 1a, b), while $D$. nisus and D. semisquamosus had a $\mathrm{Xy}_{\mathrm{p}}$ system (meioformula $8 \mathrm{II}+\mathrm{Xy}_{\mathrm{p}}$ ), with a medium $\mathrm{X}$ chromosome and a minute y chromosome, characterizing a typical parachute (Figure 1c, d).

The autosomes of the three species presented blocks of pericentromeric constitutive heterochromatin $(\mathrm{CH})$ (Figure 2). Dichotomius nisus showed an additional weak interstitial block of $\mathrm{CH}$ in the long arm of pair 1 (Figure 2a). The distribution of $\mathrm{CH}$ in D. semisquamosus was inconclusive but most of the chromosomes had pericentromeric blocks (Figure 2b). The $\mathrm{CH}$ blocks of this species were smaller than those of $D$. nisus and D. sericeus. The $\mathrm{X}$ chromosome of $D$. nisus presented a $\mathrm{CH}$ pericentromeric block, while in D. sericeus the $\mathrm{CH}$ was located in the short arm of the $\mathrm{X}$ chromosome. The y chromosome was heterochromatic in D. sericeus and euchromatic in D. nisus (Figure $2 \mathrm{a}, \mathrm{c}$ ).

Silver nitrate staining revealed amorphous masses corresponding to the nucleolar remnants (NORs) in the three species and associated to the sexual bivalent in $D$. nisus (Figure 3c). Analyses of different cells indicated that the NOR is probably associated with an autosome in $D$. sericeus (Figure 3a). The results also indicated that the NOR was present in one medium autosome pair in $D$. semisquamosus (data not shown). The corresponding heterochromatic areas were also stained by silver nitrate in different meiotic phases (Figure 3b). FISH with the 28S

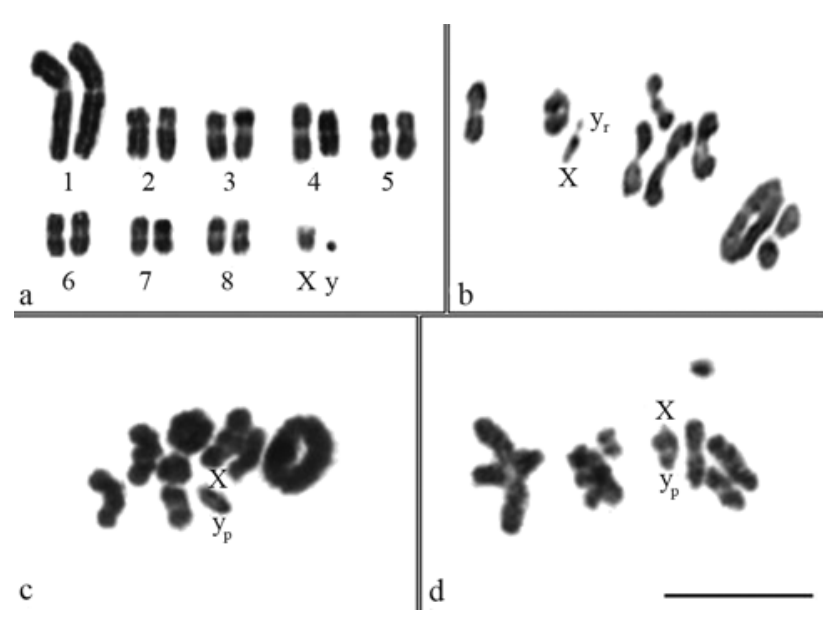

Figure 1 - Meiotic and mitotic cells of Dichotomius sericeus (a, b), D. nisus (c) and D. semisquamosus (d): (a) spermatogonial karyotype, $2 \mathrm{n}=18$; (b) metaphase I showing the $\mathrm{Xy}_{\mathrm{r}}$ mechanism, $\mathrm{n}=8 \mathrm{II}+\mathrm{Xy}_{\mathrm{r}}$; (c) metaphase $\mathrm{I}, \mathrm{n}=8 \mathrm{II}+\mathrm{Xy}_{\mathrm{p}}$; (d) diakinesis with an overlap of two autosomal pairs, $\mathrm{n}=8 \mathrm{II}+\mathrm{Xy}$. . Bar $=10 \mu \mathrm{m}$. 
rDNA probe confirmed the distribution pattern of rDNA clusters already observed after silver staining in $D$. nisus and D. semisquamosus (Figure $3 \mathrm{~d}-\mathrm{f}$ ).

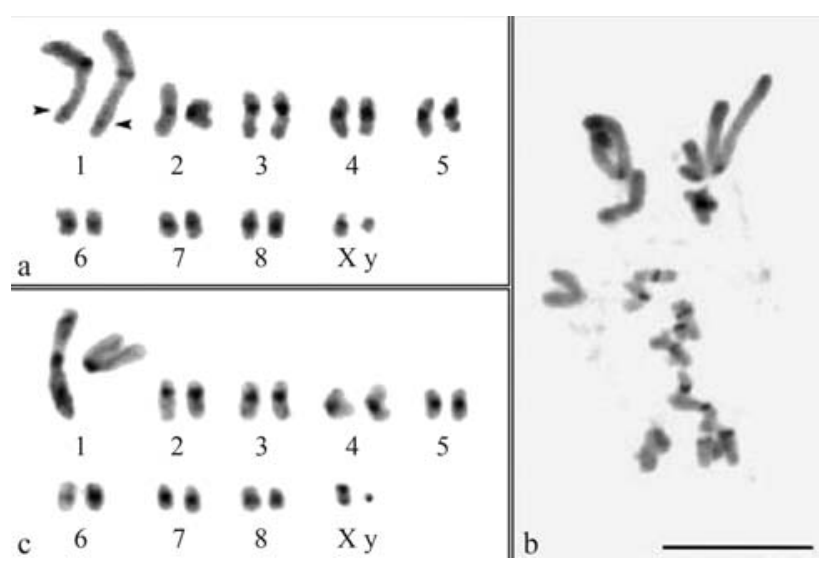

Figure 2 - C-banding in spermatogonial metaphases of Dichotomius nisus (a), D. semisquamosus (b) and D. sericeus (c). The arrowheads in (a) indicate the weak interstitial $\mathrm{CH}$ block. Bar $=10 \mu \mathrm{m}$.

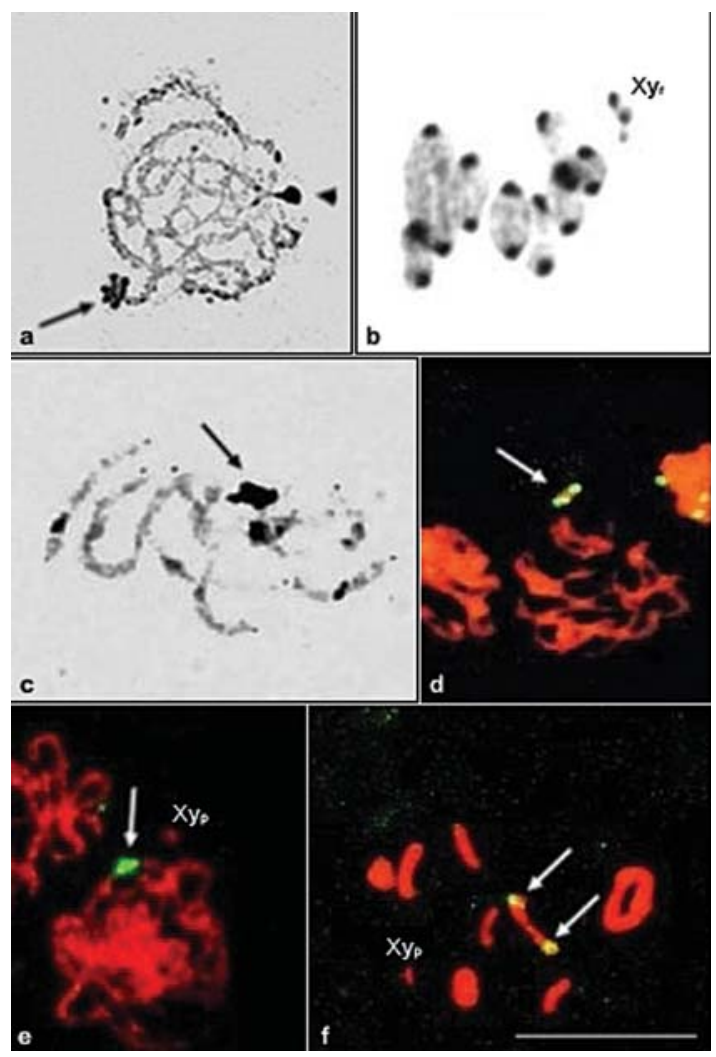

Figure 3 - Silver staining of the nucleolar organizer regions (NORs), and of the constitutive heterochromatin and rDNA sites in Dichotomius sericeus (a, b), D. nisus (c, d) and D. semisquamosus (e, f). (a) Pachytene with a totally stained autosomal bivalent (arrow), the arrowhead points to the sexual bivalent; (b) Metaphase I with silver stained heterochromatic segments. Note the $\mathrm{Xy}_{\mathrm{r}}$ sexual bivalent; (c) Pachytene with a totally stained sexual bivalent (arrow); (d, e) Pachytene and (f) Metaphase I showing the rDNA sites (arrows). Note the $\mathrm{Xy}_{\mathrm{p}}$ sexual bivalent. Bar $=10 \mu \mathrm{m}$.

\section{Discussion}

Around half of the species of the subfamily Scarabaeinae cytogenetically analyzed presented variation in diploid number or in the sex determination mechanism $\left(2 \mathrm{n}=20, \mathrm{Xy}_{\mathrm{p}}\right)$ considered primitive in the family Scarabaeidae and for the order Coleoptera (Smith and Virkki, 1978). Scarabaeinae is the most karyotypically diverse subfamily of Scarabaeidae, with variation in diploid numbers and sex determining mechanisms (Yadav and Pillai, 1979; Martins, 1994; Colomba et al., 1996; Vitturi et al., 2003; Bione et al., 2005a, 2005b, Cabral-de-Mello et al., 2008).

The three species of Dichotomius analyzed herein, as well as $D$. anaglypticus $(=D$. bos) (Vidal, 1984) and $D$. geminatus (Cabral-de-Mello et al., 2008) presented a karyotype with $2 \mathrm{n}=18$ and biarmed chromosomes. The relatively large size of pair 1 , which corresponded to the largest element of the complement, characterized a karyotypic asymmetry in these species. The reduction of the diploid number to $2 n=18$ and the relatively larger size of pair 1 when compared to the other chromosomes of the karyotype suggests the occurrence of a pericentric inversion followed by a fusion between autosomes from an ancestral karyotype with $2 n=20$. Similar rearrangements have already been described and represent the main karyotypic changes involved in the chromosomal evolution of Scarabaeidae (Yadav and Pillai, 1979, Bione et al., 2005a, 2005b; Cabral-de-Mello et al., 2007, 2008). Other species of the genus Dichotomius, such as Pinotus carolinus (= Dichotomius carolinus) and D. bosqui, conserved the primitive $2 \mathrm{n}=20$ karyotype (Smith and Virkki, 1978; Vidal, 1984).

Dichotomius nisus and D. semisquamosus showed an achiasmatic $\mathrm{Xy}_{\mathrm{p}}$ sex determination mechanism, considered primitive for Scarabaeidae. This mechanism has also been described in other species of Dichotomius (Smith and Virkki, 1978; Yadav et al., 1979; Vidal, 1984, Cabral-deMello et al., 2008). Dichotomius sericeus presented a $\mathrm{Xy}_{\mathrm{r}}$ sex determination mechanism, less frequent for Scarabaeidae and only reported in five Scarabaeinae: Catharsius sp., C. molosus, Onthophagus bonasus (= Diginthophagus bonasus), $O$. catta (= D. gazella) and $O$. dama; in one Melolonthinae: Autoserica sp.; and in four Rutelinae: Adorrhinyptia sp., Anomalous lucens, Strigodermella protea and Ectinohoplia rufipes (Smith and Virkki, 1978; Yadav et al., 1979).

Dichotomius sericeus, D. nisus and D. semisquamosus presented pericentromeric constitutive heterochromatin $(\mathrm{CH})$, a pattern also observed in other Coleoptera (Colomba et al., 2000a, 2000b; Moura et al., 2003; Rozek et al., 2004; Bione et al., 2005a, 2005b). Several $\mathrm{CH}$ distribution patterns have been described in Scarabaeidae. Eucranium arachnoids, for instance, presented pericentromeric C-banded regions and telomeric heterochromatic blocks in pairs 4, 6, 8 and in the X chromo- 
some; no CH was observed in pair 1 and in the $\mathrm{Y}$ chromosome (Vidal and Nocera, 1984). In Bubas bison, besides the pericentromeric $\mathrm{CH}$, additional distal heterochromatic blocks were reported in eight chromosome pairs (Colomba et al., 1996, 2006). Isocopris inhiata and Diabroctis mimas possessed large $\mathrm{CH}$ blocks, which corresponded to the whole short arms of pairs $3,4,5$ and 7 in the first species, and to the short arms of pairs 2, 4 and 7 in the latter species. The $\mathrm{X}$ chromosomes of these species were almost totally heterochromatic (Bione et al., 2005a).

Silver nitrate staining of $\mathrm{CH}$ in $D$. nisus, $D$. semisquamosus and $D$. sericeus was similar to the patterns reported for other species of Scarabaeoidea, as Bubas bison, Pelidnota pallidipenis, Dorcus parallelipipedus and Thorectes intermedius (Vitturi et al., 1999; Colomba et al., 2000b, 2006; Bione et al., 2005b). The silver nitrate staining did not depend on the composition of the $\mathrm{CH}$, but was possibly related to proteins associated with these areas.

The absence of silver nitrate staining in the sexual bivalent of $D$. sericeus corroborated the occurrence of the derived $\mathrm{Xy}_{\mathrm{r}}$ mechanism. In other species with $\mathrm{Xy}_{\mathrm{p}}$, the lumen of this bivalent was stained by silver due to the presence of argyrophilic proteins. According to Virkki et al. (1990; 1991), these proteins possess an adhesive function between the sex chromosomes, controlling their association and correct segregation during meiotic metaphase I and anaphase I, respectively.

The most common NORs distribution pattern reported in Coleoptera is one autosomal pair bearing the nucleolar organizer. In Scarabaeidae, NORs are frequently distributed in a single autosomal pair or in the sexual bivalent (Virkki, 1983; Colomba et al., 2000a; Moura et al., 2003; Vitturi et al., 2003; Bione et al., 2005a, 2005b). Variation in NORs location was observed in the species studied herein. In Dichotomius semisquamosus and D. sericeus, the NORs were restricted to autosomes. This pattern was also found by Moura et al. (2003) in Phyllophaga (Phyllophaga) aff. capillata after silver nitrate staining and FISH. In D. nisus the NOR was located in the sexual bivalent, as was also reported for Phyllophaga (Phytalus) vestita and Lyogenys fuscus (Moura et al., 2003).

Other NOR distribution patterns have been described in Scarabaeidae, as in Bubas bison $(2 \mathrm{n}=20)$, which has rDNA sites in eight chromosomes. This represents the largest number of NORs observed in this family (Colomba et al., 2006). Diabroctis mimas presented NORs in two autosome pairs and in the $\mathrm{X}$ chromosome (Bione et al., 2005a).

The NOR distribution patterns suggest that chromosome rearrangements involving the rDNA-bearing chromosomes were important during the evolution of this group. In D. minas, for example, it was proposed that a fission in a NOR-bearing autosome followed by its translocation to the $\mathrm{X}$ chromosome would explain the presence of rDNA sites in this chromosome (Bione et al., 2005a).
This work presents the first chromosome banding data for the genus Dichotomius. The species showed the same reduced diploid number $2 \mathrm{n}=18$, suggesting that fusions occurred during the chromosome evolution of the group. In spite of the $2 \mathrm{n}$ conservation, the different species presented various sex determining mechanisms, variable sizes of $\mathrm{CH}$ blocks and of NORs distribution. These data associated with reports from the literature corroborate the occurrence of karyotypic variability in the genus Dichotomius.

\section{Acknowledgments}

We are grateful to Dr. Sérgio Ide from the Instituto Biológico, São Paulo, and to Master Fernando Augusto Barbosa Silva, Universidade de Pernambuco/UPE, for the taxonomic identifications, and to Francisca Tavares de Lira and Cirlene Maria da Silva for the technical support. This work was supported by grants from the Conselho Nacional de Desenvolvimento Científico e Tecnológico (CNPq) Edital Universal/2004/CNPq (Processo 471485) - and Fundação de Amparo à Ciência e Tecnologia do Estado de Pernambuco (FACEPE)-PPP/MCT/CNPq/CT-INFRA/ FACEPE (Processo 006/2003).

\section{References}

Angus RB, Wilson CJ and Mann DJ (2007) A chromosomal analysis of 15 species of Gymnopleurini, Scarabaeini and Coprini (Coleoptera, Scarabaeidae) Tijdschr Entomol 150:201-211.

Bione EG, Camparoto ML and Simões ZLP (2005a) A study of the constitutive heterochromatin and nucleolus organizer regions of Isocopris inhiata and Diabroctis mimas (Coleoptera, Scarabaeidae, Scarabaeinae) using C-banding, $\mathrm{AgNO}_{3}$ staining and FISH techniques. Genet Mol Biol 28:111-116.

Bione EG, Moura RC, Carvalho R and Souza MJ (2005b). Karyotype, $\mathrm{C}$ - and fluorescence banding pattern, NOR location and FISH study of five Scarabaeidae (Coleoptera) species. Genet Mol Biol 28:376-381.

Cabral-de-Mello DC, Silva FAB and Moura RC (2007) Karyotype characterization of Eurysternus caribaeus: The smallest diploid number among Scarabaeidae (Coleoptera, Scarabaeoidea). Micron 38:323-325.

Cabral-de-Mello DC, Oliveira SG, Ramos IC and Moura RC (2008) Karyotype differentiation patterns in species of the subfamily Scarabaeinae (Scarabaeidae, Coleoptera). Micron 38:1243-1250.

Colomba MS, Monteresino E, Vitturi R and Zunino Z (1996) Characterization of mitotic chromosomes of the scarab beetles Glyphoderus sterquilinus (Westwood) and Bubas bison (L.) (Coleoptera, Scarabaeidae) using conventional and banding techniques. Biol Zentralbl 115:58-70.

Colomba MS, Vitturi R and Zunino M (2000a) Karyotype analysis, banding, and fluorescent in situ hybridization in the scarab beetle Gymnopleurus sturmi McLeady (Coleoptera, Scarabaeoidea, Scarabaeidae). J Hered 91:260-264.

Colomba MS, Vitturi R and Zunino M (2000b) Chromosome analysis and rDNA FISH in the stag beetle Dorcus 
parallelipipedus L. (Coleoptera, Scarabaeoidea, Lucanidae). Hereditas 133:249-253.

Colomba MS, Vitturi R, Libertini A, Gregorini A and Zunino M (2006) Heterochromatin of the scarab beetle, Bubas bison (Coleoptera, Scarabaeidae) II. Evidence for AT-rich compartmentalization and a high amount of rDNA copies. Micron 37:47-51.

Costa C (2000) Estado de conociemento de los Coleoptera Neotropicales. In: Martín-Piera FJ, Morrone JJ and Melic A (eds) Hacia un Proyecto CYTED para el Inventario y Estimación de la Diversidad Entomologica en Iberoaméica: PrIBES-2000. Monografías Tercer Milenio v. 1. SEA, Zaragoza, pp 99-114.

Dutrillaux AM, Xie H and Dutrillaux B (2007) High chromosomal polymorphism and heterozygosity in Cyclocephala tridentate from Guadalupe: Chromosome comparison with some other species of Dynastinae (Coleoptera, Scarabaeidae). Cytogenet Genome Res 119:248-254.

Martins VG (1994) The chromosomes of five species of Scarabaeidae (Polyphaga, Coleoptera). Naturalia 19:89-96.

Mascaine N, Dutrillaux AM and Dutrillaux B (2007) Meiotic behavior of a new complex X-Y-autosome translocation and amplified heterochromatin in Jumnos ruckeri (Saunders) (Coleoptera, Scarabaeidae, Cetoniinae). Chromosome Res 14:909-918.

Moura RC, Souza MJ, Melo NF and Lira-Neto AC (2003) Karyotypic characterization of representatives from Melolonthinae (Coleoptera, Scarabaeidae): Karyotypic analysis, banding and fluorescent in situ hybridization (FISH). Hereditas 138:200-206.

Natarajan AT, Santos SJ, Darroudi F, Hadjidikova V, Vermeulen S, Chatterjee S, Berg M, Grigorova M, Sakamoto-Hojo ET, Granath F, et al. (1998) ${ }^{137}$ Cesium-induced chromosome aberrations analyzed by fluorescence in situ hybridization: Eight years follow up of the Goiania radiation accident victims. Mutat Res 400:299-312.

Ratcliffe BC, Jameson ML and Smith ABT (2002) Scarabaeoidea Latreille 1802. In: Arnett RH, Thomas M, Skelley and Frank JH (eds) American Beetles, v. 2. CRC Press, Boca Raton, pp 39-81.

Rozek M, Lachowska D, Petitpierre E and Holecová M (2004) C-bands on chromosomes of 32 beetle species (Coleoptera, Elateridae, Cantharidae, Oedemeridae, Cerambycidae, Anthicidae, Chrysomelidae, Attelabidae and Curculionidae). Hereditas 140:161-170.

Rufas JS, Giménez-Abian J, Suja JA and Garcia de La Vega C (1987) Chromosome organization in meiosis revealed by light microscope analysis of silver-stained cores. Genome 29:706-712.
Sakamoto-Hojo ET, Natarajan AT and Curado MP (1999) Chromosome translocations in lymphocytes from individuals exposed to Cs-137 7.5 years after the accident in Goiania (Brazil). Radiat Prot Dosim 86:25-32.

Smith SG and Virkki N (1978) Coleoptera. Animal Cytogenetics, v. 3. Borntraeger, Berlin, 366 pp.

Sumner AT (1972) A simple technique for demonstrating centromeric heterochromatin. Exp Cell Res 75:304-306.

Vaz-de-Mello FZ (2000) Estado de conhecimento dos Scarabaeidae s. str (Coleoptera, Scarabaeoidea) do Brasil. In: Martín-Piera F, Morrone JJ and Melic A (eds) Hacia un Proyecto CYTED para el Inventario y Estimación de la Diversidad Entomológica en Iberoamérica. SEA, Zaragoza, pp 181-195.

Vidal OR (1984) Coleoptera from Argentina. Genetica 65:235239.

Vidal OR and Nocera CP (1984) Citogenética de la tribu Eucranini (Coleoptera, Scarabaeidae). Estúdios convencionales y con bandeo C. Physis 42:83-90.

Virkki N (1983) Banding of Oedionychna (Coleoptera, Alticinae) chromosomes: C- and Ag-bands. J Agric Univ Puerto Rico 67:221-225.

Virkki N, Mazzella C and Denton A (1990) Staining of substances adjacent to the $\mathrm{Xy}_{\mathrm{p}}$ sex bivalent of some weevils (Coleoptera, Curculionidae). J Agric Univ Puerto Rico 74:405-418.

Virkki N, Mazzella C and Denton A (1991) Silver staining of the coleopteran $\mathrm{Xy}_{\mathrm{p}}$ sex bivalent. Cytobios 67:45-63.

Vitturi R, Colomba MS, Barbieri R and Zunino M (1999) Ribosomal DNA location in the scarab beetle Thorectes intermedius (Costa) (Coleoptera, Geotrupidae) using banding and fluorescent in-situ hybridization. Chromosome Res 7:255-260.

Vitturi R, Colomba M, Volpe N, Lannino A and Zunino M (2003) Evidence for male XO sex-chromosome system in Pentodon bidens punctatum (Coleoptera, Scarabaeoidea, Scarabaeidae) with X-linked 18S-28S rDNA clusters. Genes Genet Syst 78:427-432.

Yadav JS and Pillai RK (1979) Evolution of karyotypes and phylogenetic relationships in Scarabaeidae (Coleoptera). Zool Anz 202:105-118.

Yadav JS, Pillai RK and Karamjeet (1979) Chromosome numbers of Scarabaeidae (Polyphaga, Coleoptera). Coleopt Bull 33:309-318.

Wilson CJ and Angus RB (2005) A chromosomal analysis of 21 species of Oniticellini and Onthophagini (Coleoptera, Scarabaeidae). Tijdschr Entomol 148:63-76.

Associate Editor: Yatiyo Yonenaga-Yassuda

License information: This is an open-access article distributed under the terms of the Creative Commons Attribution License, which permits unrestricted use, distribution, and reproduction in any medium, provided the original work is properly cited. 